\title{
Prietenia - cale de cunoaștere a lui Dumnezeu prin oameni
}

Alin Gabi NICA*

Abstract: In the pages of Holy Scripture and the writings of the Church Fathers we find references showing that friendship is a virtue. This brings to the fore the links between people in different ways are presented as the manifestation way can be both vertically and horizontally. St. Paul prayed fall from glory future life for the salvation of others. This proves that greater love it there (cf. Jn 15, 13). So St. John Chrysostom which has exposed the example of Moses, Abraham, Jacob, Joseph and David who made friends on foreground interest so earned glory, not as he did in Lot selfishly.

Keywords: teognosie, virtue, communion, love, person

Tema prieteniei este un subiect abordat în foarte multe

* PhD candidate, Department of Orthodox Theology, Bucharest University, Bucharest, Romania. 


\section{Alin Gabi NICA}

împrejurări și a fost tratată dintr-o mulțime de puncte de vedere: social, religios, cultural, filantropic, etc. Pentru a avea un punct de plecare, să vedem cum este definit acest cuvânt în Dicționarul explicativ al limbii române 2 : Prietenie: s. f. Sentiment de simpatie, de stimă, de respect, de atașament reciproc care leagă două persoane; legătură care se stabilește între persoane, pe baza acestor sentimente; amiciție, prieteșug; atitudine plină de bunăvoință, prietenoasă față de cineva; legătură între grupuri sociale, între popoare, între țări bazată pe aspirații, năzuințe, interese comune. Așadar, prietenia este în primul rând un sentiment, o trăire din cele mai profunde, față de o altă persoană cu care are avem o anumită legătură. Prietenia este și o atitudine pozitivă față de cineva, de o altă persoană, dar după cum vedem poate fi și un sentiment între popoare sau grupuri, așadar prietenia are o valoare universală și o regăsim la nivel personal cât și la nivel de grupuri de persoane.

Omul este o ființă socială, el depășește individualitatea lui prin manifestarea sub raport social cu cel de lângă el. Sociabilitatea

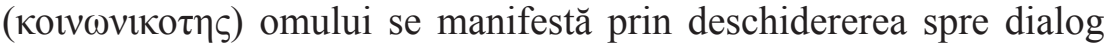
către un alt ego. Omul iese în afara lui prin acest raport interpersonal cu cel de lângă el: „depășirea individualismului se realizează prin iubirea către Dumnezeu și către aproapele"3. Biologia contemporană confirmă unitatea incontestabilă a oamenilor între ei, dar și a oamenilor cu natura: „,cunoaștem deja că toți oamenii, independent de rasă și sex, sunt identici în proporție de 99,9\%". Aceste date analizate empiric ne arată că diferențele dintre oamenii din întreaga lume se limtează la o miime a genotipului lor. Având atât de multe în comun ar fi trebuit ca relațiile dintre oameni să fie foarte armonioase, dar totuși privind în jur, vedem că prietenia adevărată este floare rară. Cum se poate

${ }^{2}$ Dicționarul explicativ al limbii române, București, Edit. Academiei R.S.R., 1975.

${ }^{3}$ Georgios Manztaridis, Morala creștină, București, Edit. Bizantină, 2006, p. 265.

${ }^{4}$ Vezi James Shreeve, Secretele genelor, National Geografic, tom.3, Octombrie 1999, p. 127. 
explica acest lucru? Putem explica lipsa colaborării armonioase dintre oameni prin lipsa raportării la veșnicie, prin limitarea existenței omului doar în planul vieții fizice, iar acest lucru face ca să existe răceala dintre oameni, egoism, egocentrism, cirumscrierea acțiunilor individului către sine și nu către celălalt.

Pentru a vedea ce înseamna cu adevărat virtutea prieteniei și cum ne poate ajuta aceasta să îl cunoaștem pe Dumnezeu-Persoană trebuie să căutăm temeiuri în Sfânta Scriptură și Sfânta Tradiție.

\section{Virtutea prieteniei întemeiată pe Sfânta Scriptură și Sfinții Părinți}

Prietenia este o virtute de mare preț, de aceea trebuie cultivată și crescută prin asculatarea cuvintelor din Sfânta Scriptură. Atât în Vechiul Testament cât și în Noul Testament, găsim multe temeiuri biblice care ne arată cât este de prețioasă este această formă de manifestare interumană.

Astfel, înţeleptul Solomon spunea: „Prietenul adevărat iubeşte oricând şi în nenorocire ajunge ca un frate” (Prov. 17,17) sau: „Rănile făcute de un prieten dovedesc credincioşia lui'"(Prov. 27,6) iar mai departe găsim: „Cum înveseleşte untdelemnul şi tămâia inima, aşa de dulci sunt sfaturile pline de dragoste ale unui prieten”(Prov. 27,9).

Ni se măsoară cu aceeaşi măsură cu care măsurăm noi, căci ,ce seamănă omul aceea va secera"'(Gal. 6,7). Încrederea reciprocă este prima necesitate pentru a-ţi crea prieteni, iar credincioşia este condiţia principală pentru păstrarea lor. Cel mai bun mijloc de întreţinere al prieteniei este aplicarea regulii de aur: „Tot ce voiţi să vă facă vouă oamenii faceţi-le şi voi la fel"'(Mat. 7,12).

$\mathrm{Nu}$ învăţăm decât de la Cel ce ne iubeşte dezinteresat şi necondiţionat: ,împrieteneşte-te dar cu Dumnezeu şi vei avea pace, te vei bucura astfel iarăşi de fericire"(Iov 22.21).

Sfântul Ioan Gură de Aur înalţă dragostei şi prieteniei imne pline de înțelepciune în multe din operele sale. Pentru el, dragostea 
și prietenia între oameni nu au un înțeles lipsit de conţinut, ci unul pentru care viaţa merită trăită: ,ce se poate asemăna cu dragostea? Nimic! Ea este rădăcina, izvorul şi mama bunătăţilor, virtute care nu produce suferinţă, virtute plină de plăcere şi aducând multă bucurie acelora care o exercită"'s. În concepţia Sfântului Ioan, prietenia, pentru ca să fie puternică și trainică, trebuie să aibă temei, motiv şi model pe Hristos, care Şi-a dat viaţa pentru prietenii Săi (Ioan 15,13).

Marele arhipăstor precizează că prietenia este unirea atât de strânsă între cel ce iubeşte şi cel iubit, încât să nu mai fie două persoane deosebite, ci un singur om, întărind ideea că prietenul este un alter ego, un alt eu: ,dacă ai douăzeci de prieteni, vezi cu încă douăzeci de ochi, lucrezi cu încă douăzeci de mâini, mergi cu încă douăzeci de picioare. Un ins poate să fie datorită prietenilor în mai multe locuri deodată în acelaşi timp".

Într-adevăr, în concepţia Sfântului, dacă cineva are un duşman, atunci acel dușman nu este atacat numai de o singură persoană, ci și de cele douăzeci, și atunci trebuie ca duşmanul să cedeze, pentru că el nu este respins de o singură persoană, ci de douăzeci. Dacă unul ar fi lipsă, el nu este pentru aceea în pericol; el este bogat prin partea cea mare, prin ceilalţi douăzeci; şi partea care cade este astfel susţinută, cea mai slabă, prin cel mai puternic. El nu mai merge singur prin picioarele sale, ci şi prin cele ale celorlalţi; el nu lucrează numai prin mâinile sale, ci şi prin ale celorlalţi. Fiecare din ei are zece suflete; fiindcă nu are numai el unul singur grijă de lucrurile sale, ci și ceilalţi au la fel. Şi dacă ar fi aşa o sută sau o mie uniţi împreună, va fi la fel, şi puterea se va adăuga în proporţie cu numărul.

Pe parcursul vieţii sale, Sfântul Ioan a întâlnit oameni care au dorit să-1 compromită sau să-i suprime viaţa, dar şi prieteni adevăraţi şi devotaţi care i-au oferit ajutorul în vremurile tulburi şi au luptat pentru el cu abnegaţie. Marele predicator, prin următoarele graiuri își

${ }^{5}$ Scrisoarea 222, P. G. LII, col. 733-734.

${ }^{6}$ Omilia LXXVIII, 4 la Ioan, P. G. LIX, col. 425. 
exprima convingerea că ,,prietenul sincer este cu mult mai dorit decât chiar lumina. Şi să nu te miri că zic aceasta, pentru că mai bine ne-ar fi dacă s-ar stinge soarele, decât a fi lipsiţi de prieteni adevărați; mai bine ne-ar fi de a trăi în întuneric decât de a fi fără prieteni. Şi cum este aceasta, eu vă voi spune. Mulţi văzând soarele, sunt în întuneric, pe când dacă sunt înconjuraţi de prieteni, nu ar suferi nici o scârbă. Eu vorbesc de prietenia cea duhovnicească şi de prietenii duhovniceşti, care nimic nu preferă înaintea prieteniei"”.

Referindu-se la felurile prieteniei şi pricinile pe care se întemeiază ea, Sfântul Ioan își exprima nemulțumirea și mâhnirea pentru faptul că ,... nu ne întărim cu dragostea cea după Dumnezeu, ci căutăm alte pricini de prietenie: unii neamurile, alţii obişnuinţa, alţii tovarăşii de slujbă, alţii vecinii; orice altă pricină, afară de credinţa în Dumnezeu; şi ar trebui ca numai credința în Dumnezeu să lege pe prieteni. Lucrurile însă se petrec cu totul dimpotrivă; suntem prieteni cu iudeii şi cu păgânii, şi nu suntem prieteni cu fiii Bisericii”" . Prieteniile cele rele sunt prezentate în opera marelui Hrisostom mai groaznice decât duşmăniile. „Nu ţine, dar, lângă tine prieteni care sunt dascălii pagubei tale! Nu ţine lângă tine prieteni care îndrăgesc mai mult masa ta decât prietenia ta! Că toţi aceştia termină şi cu prietenia odată ce au terminat masa şi petrecerea; ceilalţi însă, prietenii de dragul virtuţii, rămân veşnic lângă tine, îndură alături de tine toate durerile şi toate necazurile tale. Prietenii de masă şi de beţii, neamul paraziţilor, de multe ori se răzbună pe tine şi-ţi fac nume prost"”. În general, suntem etichetați de către ceilalți și în funcție de prietenii noștri. În acest sens, Sfântul arhiepiscop accentuează următoarele: „Cunosc mulţi oameni vrednici care au căpătat o faimă proastă, făcută

${ }^{7}$ Sf. Ioan Gură de Aur, Comentariile sau Explicarea Epistolei I către Tesaloniceni, omilia II, în vol. „Comentariile sau Explicarea Epistolei către Coloseni, I şi II Tesaloniceni”, p. 179.

${ }^{8}$ Sf. Ioan Gură de Aur, Omilii la Matei, omilia LIX, V, în col. „PSB”, vol. 23, p. 692 .

${ }^{9}$ Idem, p. 565. 


\section{Alin Gabi NICA}

tocmai de prietenii lor de chefuri şi beţii; au spus despre dânşii că sunt nişte şarlatani, nişte desfrânaţi care strică casele altora, nişte corupători de copii. Şi lumea le dă crezare, crede că trăiesc cu copiii, odată ce nu se ocupă cu nimic şi-şi irosesc viaţa fără rost"10.

Maestru al cuvântului și stăpân al nuanțelor, Sfântul Ioan prezintă în termeni encomiastici prietenia duhovnicească ce nu urmăreşte foloase personale, ci slujeşte dezinteresat unor idealuri sublime: ,pentru că oamenii se unesc între ei pe temeiul acestor pricini trecătoare, de aceea nici prieteniile dintre ei nu sunt nici călduroase, nici nu dăinuiesc. Se întrerupe dragostea de se iscă între ei insulte, pagube de bani, invidie, dragoste de slavă deşartă şi altele la fel cu acestea. Se întrerupe dragostea, că nu are rădăcină duhovnicească. Dacă ar fi avut o astfel de rădăcină, nici o pricină lumească n-ar fi stricat dragostea duhovnicească.

Dragostea de aproapele întemeiată pe dragostea de Hristos este trainică, nestricată, nebiruită, nesfărâmată. N-o pot sfărâma nici calomniile, nici primejdiile, nici moartea, nici altceva asemănător. Orice ar pătimi un om care iubeşte aşa pe aproapele său nu va înceta niciodată a-l iubi, pentru că se uită la pricina dragostei sale, la Hristos. Dar cel care iubeşte pentru că e iubit şi el la rândul său, o termină repede cu dragostea dacă prietenul său îl supără cu ceva; dimpotrivă, cel legat de semenul său cu lanţul dragostei de Hristos niciodată nu va pune capăt prieteniei"'11. In alt loc, același autor patristic precizează: „Prietenii adevăraţi covârşesc pe părinţi şi pe fii, vorbesc de prietenii cei după Hristos"'12.

În acest sens, marele arhipăstor ne lansează tuturor nenumărate exortații în a căuta să legăm strânse prietenii cu aceia care pot să ne pună în bună rânduială totdeauna sufletele noastre, să ne dea sfaturi

\footnotetext{
${ }^{10}$ Ibidem.

${ }^{11}$ Sf. Ioan Gură de Aur, Omilii la Matei, omilia LIX, III, p. 594.

${ }^{12}$ Sf. Ioan Gură de Aur, Comentariile sau Explicarea Epistolei I către Tesaloniceni..., p. 182.
} 
de suflet mântuitoare, să ne mustre când păcătuim, să ne arate când greşim, să ne ridice când cădem, să ne îndrepte spre Dumnezeu, ajutându-ne cu sfatul şi cu rugăciunile.

Aceasta este de fapt și îndatorirea unui adevărat prieten și scopul suprem al oricărei prietenii: întrajutorarea și sprijinul reciproc pentru mântuirea sufletului și unirea cât mai deplină cu Dumnezeu. În acest fel se și deosebește un prieten de un lingușitor: primul ne arată - cu dragoste și bunăvoință- și faptele sau cuvintele noastre de scădere, dorind îndreptarea și desăvârșirea noastră în Hristos, pe când lingușitorul ne scoate la lumină și ne relevă, într-un mod exagerat de cel mai multe ori, numai faptele cele bune, ascunzând greșelile, pentru a urmări anumite beneficii materiale de pe urma noastră. „Că şi eu îl iubesc pe cel ce mă iubeşte, iar când mă mustră şi mă huleşte pentru îndreptarea unei greşeli, atunci mai mult îmi pare că mă iubeşte, că cel ce laudă pe prietenul său de ar face ori rău ori bine, acela nu este prieten adevărat, ci înşelător şi făţarnic; când laudă cineva pe cel ce face lucruri bune sau îl mustră pe cel ce face cele rele, şi-l mustră în taină, adică să fie numai ei amândoi, atunci este lucru de prieten credincios şi iubit; şi când mă laudă vreun vrăjmaş al meu, nici nu primesc, iar pe prieten când mă ceartă, îl iubesc şi dragi îmi sunt rănile lui, precum zice cuvântul filosofic. Mai credincioase sunt rănile prietenului, decât sărutarea cea de bună voie a vrăjmaşului, pentru că vrăjmaşul, ori cu dreptate ori cu strâmbătate de ocărăşte şi mustră pe om, nu spre folosul lui o face, ci ca să-i facă ruşine"'13. Întradevăr, atunci când ne critică prietenii, pe drept sau pe nedrept, nu o fac cu gând batjocoritor sau de ocară, ci spre îndreptare. Duşmanii, însă, chiar când ne mustră și ne critică pe drept nu ne critică pentru a ne schimba și transfigura, ci încearcă să ne facă de batjocură. Prietenii când ne laudă, caută să ne facă mai buni; duşmanii, însă, chiar când ne laudă se străduiesc să ne doboare.

${ }^{13}$ Theodosie Athanasiu, Mărgăritarele Sfântului Ioan Gură de Aur, traducere de diacon Gheorghe Băbuţ, Oradea, Editura „Pelerinul Român”, 1994, p. 62. 


\section{Prietenul - chipul lui Dumnezeu care privește spre noi}

Întâlnirea cu oamenii se face și ea prilej de comuniune și de creștere în iubire. $\mathrm{Cu}$ cât ne unim mai mult în dragoste, cu semenii, cu atât ne apropiem mai mult de cunoașterea și iubirea lui Dumnezeu. Suntem astfel ca niște puncte pe marginea unui cerc, ca niste raze ale lui, și cu cât ne apropiem de razele alăturate, cu atât ne apropiem de centrul cercului.

Mulți oameni au nevoie de noi, așa cum și noi, la rândul nostru, avem nevoie de alții. Dumnezeu se ascunde adesea în spatele celor de lângă noi, iar noi, pentru a ajunge la el, trebuie să iubim mai întâi pe aceștia după care se ascunde. Minunat spune părintele Stăniloae: „În fiecare sărac și asuprit și bolnav ne întâmpină Hristos, cerândune, prin coborâre, ajutorul nostru. În mâna întinsă a săracului e mâna întinsă a lui Hristos, în vocea lui stinsă, auzim vocea stinsă a lui Hristos; suferința lui, din pricina lipsei și a umilinței în care-l ținem, e suferința lui Hristos pe cruce, pe care noi o prelungim; în toate, Dumnezeu se coboară la noi și ni Se face cunoscut"14.

Prin cei de lânga noi se mai lucrează însă și într-alt chip. Sunt în jurul nostru oameni care ne fac să simțim o liniște filocalică. Astfel, prin viața sfântă a unuia, mulți pot cunoaște pe Dumnezeu. Prietenia cu oamenii curați la suflet poate să producă în sufletul aproapelui o schimbare radicală a vieții lui și îl poate călăuzi spre cunoașterea tainelor lui Dumnezeu. Unii au nevoie de noi și noi avem nevoie de alții. Iar în toate acestea se ascunde zilnic Dumnezeu.

Mustrările conștiinței, după căderea noastră din iubire, și odihna inimii, pe care o simțim la facerea binelui, ne arată de fiecare dată calea spre Dumnezeu. Cu cât ne întărim în dragoste și comuniune cu semenii, cu atât Dumnezu ni se descoperă mai mult și mai direct. Persoana de lângă noi este purtătoarea chipului lui Dumnezeu dobândit la creație, de aceea noi putem să ajungem la cunoașterea lui

${ }^{14}$ Pr. Dumitru Stăniloe, Teologia dogmatică ortodoxă, Edit. EIBMOR, vol. III, București, 2010, p. 144. 
Dumnezeu prin aproapele, semenul, prietenul nostru.

Necazurile și încercările din viața de zi cu zi sunt însă cele mai puternice lucruri ce ne mișcă inima, ne trezește mintea și ne fac să căutăm spre Dumnezeu. Astfel, cunoașterea lui Dumnezeu prin tulburările zilnice, devine o cunoaștere extrem de personală și de directă, dar le fel se poate întâmpla când prietenul nostru are parte de un necaz sau îndură o suferință, căci prin atașamentul față de acesta putem ca și noi să trăim împreună cu el experiența căutării lui Dumnezeu și aflarea Lui prin rugăciune.

Bolile personale sau ale prietenilor noștri ne pun adesea în fața propriilor neputințe, în fața întrebărilor celor mari asupra rostului vieții și al lumii. El este simțit nu doar drept Creator și Proniator al lumii, în imensitatea ei, ci mai mult, drept Persoana Iubitoare, în mare purtare de grijă față de mine. Simt o atenție atotcuprinzătoare asupra problemelor, nevoilor și persoanei mele. Aceasta este prezența lui Dumnezeu, care, „vrea ceva deosebit cu mine” ${ }^{15}$. Cu toate acestea, acest raport intim al lui Dumnezeu cu mine nu mă scoate din solidaritatea cu ceilalți, căci este nevoie să fiu în raport cu cel de lângă mine pentru ca să mă adresez lui prin faptele mele: „Căci flămând am fost și Miați dat să mănânc; însetat am fost și Mi-ați dat să beau; străin am fost și M-ați primit; gol am fost și M-ați îmbrăcat; bolnav am fost și M-ați cercetat; în temniță am fost și ați venit la Mine"(Matei 25, 31-46). Împrejurările și persoanele din viața noastră sunt chipuri transparente ale lui Dumnezeu, de aceea trebuie să vedem cu ochii duhovnicești că relația de prietenie avută cu semenul nostru se arată ca o oportunitate de a-L cunoaște pe Dumnezeu în lucrarea sa creatoare.

Întâlnirile cu acei oameni, care ne rămân în minte și ne pun pe gânduri asupra vieții noastre, sunt lucrări ale lui Dumnezeu, spre a trezi pe om din uitare și nepăsare.

Sfântul Ioan Gură de Aur, spune: „Cugetul omenesc, câtă vreme se bucură de multă libertate, se revarsă și se împrăștie. Dar,

${ }^{15}$ Pr. Dumitru Stăniloae, Teologia dogmatică ortodoxă ..., p. 144. 
când vreo împrejurare de jos îl strâmtorează și îl presează puternic, trimite rugăciunile curate și frecvente spre înălțime. (...) Căci nimic nu alungă mai mult nepăsarea și moleșeala ca durerea și necazul, care adună cugetul din toate părțile și-l întoarce spre Dumnezeu".

Necazurile ca ispite și încercări sunt însă calea cea mai puternică de mișcare a inimii spre rugăciune, spre nevoința și spre tânjire după dragostea și mila lui Dumnezeu. Dumnezeu conduce pe om spre cunoașterea Sa, spre mântuire, atât prin pronia Sa, cât și prin judecata Sa. „Judecata cuprinde diferite pedepse ce ni le aduce Dumnezeu de pe urma păcatelor, ca să ne atragă de la rele, diferitele privațiuni de fericire, ca să ne îndemne să-L căutăm și mai mult"16. Ambele sunt neîncetate, atât purtarea de grijă prin pronie, cât și judecata.

Sfântul Maxim Mărturisitorul diferențiază între cele două căi de conducere, astfel: „Iubitorul de Dumnezeu este îndumnezeit prin providență; cel de-al doilea, adică iubitorul de trup și de lume, e oprit de judecată să ajungă la osândă" ${ }^{17}$ și mai departe „bucuriile sunt domolite de siguranța necazurilor ce vor veni, iar necazurile sunt răbdate cu un amestec de seninătate pentru siguranța bucuriilor ce vor urma"18.

Ispitele și încercările prin care este trecut omul au drept primă urmare o mai bună cunoaștere de sine și o conștientizare a nevoii de ajutorul lui Dumnezeu. Omul nu trebuie însă numai să se cunoască, ci să se și îndrepteze. Această autocunoaștere, autodescoperire duce implicit la descoperirea Celui ce îi poartă de grijă și îl întărește în mijlocul greutăților. Vede cum singur nu are puterea de a rezista luptelor ivite în cale, iar atunci când reușeste, simte că nu este singur, ci că un Altul i-a ajutat lui.

\footnotetext{
${ }^{16}$ Pr. Dumitru Stăniloae, Ascetica și mistica, București, Edit. EIBMOR, 2010, p. 184.

${ }^{17}$ Sf. Maxim Mărturisitorul, Răspunsuri către Talasie, trad, introducere şi note de Pr. Prof. Dumitru Stăniloae, în „Filocalia”, vol. 3, Ediţie electronică, Apologeticum, 2005.

${ }^{18}$ Pr. Dumitru Stăniloae, Ascetica și mistica..., p. 196.
} 


\section{Bibliografie:}

1. [Academia R.S.R. - Institutul de Lingvistică] Dicționarul explicativ al limbii române, București, Edit. Academiei R.S.R., 1975.

2. Athanasiu, Theodosie, Mărgăritarele Sfântului Ioan Gură de Aur, traducere de diacon Gheorghe Băbuţ, Oradea, Editura „Pelerinul Român”, 1994.

3. Manztaridis, Georgios, Morala creștină, București, Edit. Bizantină, 2006.

4. P. G.

5. Sf. Ioan Gură de Aur, Comentariile sau Explicarea Epistolei I către Tesaloniceni, omilia II, în vol. „Comentariile sau Explicarea Epistolei către Coloseni, I şi II Tesaloniceni”, Ediție electronica, Bucuresti, 1905.

6. Sf. Maxim Mărturisitorul, Răspunsuri către Talasie, trad, introducere şi note de Pr. Prof. Dumitru Stăniloae, în „Filocalia”, vol. 3, Ediţie electronică, Apologeticum, 2005.

7. Shreeve, James, Secretele genelor, Bucuresti, Edit. National Geografic, Octombrie 1999.

8. Stăniloae, Dumitru, Ascetica și mistica, Bucuresti, Editura IBMBOR, 2010.

9. Idem, Teologia Dogmatică Ortodoxă, vol. I, Bucuresti, Editura IBMBOR, 1978. 
